\title{
GIUSEPPE MONTESANO, Honoré de Balzac. 1799-1850
}

\section{Marco Stupazzoni}

\section{CpenEdition \\ Journals}

\section{Edizione digitale}

URL: http://journals.openedition.org/studifrancesi/16530

DOI: 10.4000/studifrancesi. 16530

ISSN: 2421-5856

\section{Editore}

Rosenberg \& Sellier

\section{Edizione cartacea}

Data di pubblicazione: 1 juillet 2019

Paginazione: 174-175

ISSN: 0039-2944

\section{Notizia bibliografica digitale}

Marco Stupazzoni, «giuseppe montesano, Honoré de Balzac. 1799-1850», Studi Francesi [Online], 187 (LXIII I I) | 2019, online dal 01 juillet 2019, consultato il 25 janvier 2021. URL: http://journals.openedition.org/ studifrancesi/16530 ; DOI: https://doi.org/10.4000/studifrancesi.16530

Questo documento è stato generato automaticamente il 25 janvier 2021.

\section{(c) (†)}

Studi Francesi è distribuita con Licenza Creative Commons Attribuzione - Non commerciale - Non opere derivate 4.0 Internazionale. 


\title{
GIUSEPPE MONTESANO, Honoré de Balzac. $1799-1850$
}

\author{
Marco Stupazzoni
}

\section{NOTIZIA}

GIUSEPPE MONTESANO, Honoré de Balzac. 1799-1850, in Lettori selvaggi. Dai misteriosi artisti della Preistoria a Saffo a Beethoven a Borges la vita vera è altrove, Firenze, Giunti, 2016, pp. 755-759.

1 L'azione di Balzac sulle forme, sulle strutture e sui paradigmi del romanzo ottocentesco è stata devastante. L'autore di quell'interminato e interminabile romanzo che è $L a$ Comédie humaine ha letteralmente aperto le porte alla rappresentazione delle meraviglie e degli orrori del Moderno attraverso la sublimazione visionaria di quel babelico crogiuolo di esseri, cose e ambienti che fu Parigi nel xix secolo. In questo «miscuglio adultero di tutto» (p.756), nel quale agiscono le più diverse forme del corpo e dell'anima, è il denaro che esalta e allo stesso tempo svilisce l'esistenza degli individui, che scatena le passioni più sfrenate e i desideri più segreti e che li ricompone in un sistema nuovo, in perpetuo movimento, «secondo la legge della trasformazione delle merci in immondizia e dell'immondizia in merci» (ibid.).

2 Balzac, scrive Montesano, non ha mai cercato di mimare la vita, ma «ha costruito una vita parallela a quella reale, una vita che brilla e brulica nella febbre poetica di una verità allucinatoria» (p. 757). Attraverso l'invenzione (Balzac «non pensava: inventava», p. 759), lo sguardo fantasmagorico e visionario dello scrittore ha illuminato gli spazi, gli esseri e le cose più irriducibilmente anti-letterari e anti-poetici e li ha sublimati in poesia. È questo il segreto di Balzac; è questa la modernità della sua scrittura geroglifica: è la visione, una visione che «poteva avvenire solo nella notte, la notte in cui Balzac scriveva e in cui ogni realtà è affondata nel buio che la cela, e c'è solo il foglio con le parole, le parole che si sovrappongono ad altre parole e nascono da 
altre parole, le parole che si affollano con furia e con fatica, e sotto il loro geroglifico cancellano le parvenze del mondo: lasciando al suo posto la Comédie humaine» (p. 759). 